\title{
Hans Raun Iversen, Grundtvig, folkekirke og mission
}

\author{
Af Kim Arne Pedersen
}

Hans Raun Iversen, Grundtvig, folkekirke og mission: Praktisk teologiske vekselvirkninger. Forlaget ANIS, København 2008. 567 s.

Hans Raun Iversen har engang med ægte beskedenhed udtalt, at han jo først og fremmest er en teolog, der samler og udgiver. Med udgivelsen af sin store bog i 2008 har han indirekte dementeret denne udtalelse. Der er tale om en antologi med artikler, han har forfattet $i$ årenes løb, en imponerende samling tekster, der vidner om en usædvanlig flid og om mere end 25 års engageret medleven og medtænken i kirkens og teologiens problemer. Bogen falder i tre dele efter hver sit emne, Grundtvig, folkekirke og mission - men bidragene taler med hinanden: således forekommer begreberne "kultur" og "kulturmøde" i afsnittet om mission, men det er samtidig netop de begreber, der med missionsteologien som tolkningsnøgle har kunnet inspirere til nye veje $\mathrm{i}$ arbejdet med Grundtvig, dén Grundtvig, om hvem Hans Raun Iversen siger, at han er "en vigtig teologisk sparringspartner, hvis indsigter jeg ikke blot selv støtter mig til, men også gerne bringer til torvs" (11).

Hvilken Grundtvig er det så, man møder i bogen? Først og fremmest er der tale om en praktisk teologisk læsning af især Grundtvigs kirkelige forfatterskab, gennemført med udgangspunkt i den nytolkning af Grundtvig, der indledtes med Theodor Jørgensens kritik af og debat med Kaj Thaning i tidsskriftet Fønix i årene omkring 1980, en nytolkning, som Hans Raun Iversen allerede dengang bidrog afgørende til, og som han i årenes løb har arbejdet videre på i forbindelse med sin forskning og undervisning. Praktisk teologi har i København status som en systematisk teologisk disciplin, hvilket vil sige, at den har til opgave at tænke den kristne tro i sammenhæng og med henblik på samtiden. Der er, med Hans Raun Iversens egne ord, med missionsteologi og praktisk teologi tale om to "teologiske applikationsdiscipliner" (19), der begge præges af "den karakteristiske sammenkædning af empiriske, historiske og systematisk teologisk reflekterende elementer i studierne" (10). "Begge steder" handler "det om at dykke ned i en livsform og en grundlæggende tankegang i kirke og samfund for at undersøge, hvordan kirkens teologi, praksis og kommunikation bidrager i sammenhængen" (9). Den praktiske teologis studium af den måde, kirken har skikkelse på i samfundets og folkets 
liv under de historisk givne vilkår, gennemføres således ikke som blot empirisk eller kirkehistorisk undersøgelse, men bygger bro mellem teori og praksis ved at anvise nogle mulige svar på, hvilke veje vi skal gå i dagens kirkeliv, og Hans Raun Iversens missionsteologiske erfaringer har her befrugtet hans Grundtvig-studier, ligesom han har arbejdet med Grundtvig i kontekst af den danske kirke nu. Som én af pionererne i den nye Grundtvig-tolkning har Hans Raun Iversen således bestemt forholdet mellem kristendom og menneskeliv som et vekselvirkningsforhold, idet han har betonet, at kristendommen altid må tage skikkelse i den konkrete virkelighed, som en folkeligt-kulturel sammenhæng udgør. Set i det perspektiv er det ikke urimeligt at betegne Hans Raun Iversen som kontekstuel teolog, idet man hos Raun Iversen for det første møder en markant bevidsthed om kristendommens "klassiske" indhold, for det andet en bevidsthed om forholdet til en givet kultur som bestemmende for menighedsliv og teologi - samt endelig en kritisk tilgang til sekulariseringen og dens afhængighed af økonomiske strukturer - forhold, han alle forbinder med forholdet mellem kristendom og menneskeliv i grundtvigsk forstand. Hans Raun Iversens arbejder angår således først og fremmest forholdet mellem kirke og livsform, og i analysen heraf byder vekselvirkningsbegrebet sig naturligt til:

Den mest markante tale om vekselvirkning fører Grundtvig mht. forholdet mellem det menneskelige og det kristelige eller det folkelige og det kirkelige (...) Den vekselvirkning er så oplagt og omfattende, at det er svært at indkredse den, sådan som Grundtvigs livslange kamp for både at skelne og sammenholde uden at adskille demonstrerer det. I mit arbejde har jeg ofte kogt denne (...) vekselvirkning ned til forholdet mellem det empirisk (historisk, sociologisk, antropologisk etc.) konstaterbare og den teologiske tolkning og eftertanke (11).

Hans Raun Iversen taler om et forløb af vekselvirkninger: "Budskabets virkning er aldrig uafhængig af", men i vekselvirkning med "formen og situationen i konteksten" (12). Der er tale om en "praksis-teoripraksis sammenhæng", og til dette forløb svarer også en indholdsmæssig kæde af vekselvirkninger - "Kristologisk talt handler det om den ubrudte kæde af inkarnationer, hvor mennesker får den levende Kristus for øje" (12). Den samme vekselvirkning kan man genfinde i selve bogens stil. I fremstillingen veksler fyldige citater sommetider på mere end én side - med Hans Raun Iversens egen redegørelse for Grundtvigs teologi. Hans Raun Iversen bruger nutidige teologiske formuleringer - nøgleord, formler, samlende problemstillinger - som tolkningsnøgler til Grundtvigs forfatterskab, med hans egne ord "teologisk(e) tankestruktur(er)" (92), som udgør den - "dybe sammenhæng" i Grundtvigs forfatterskab. Et karakteristisk eksempel 
på Hans Raun Iversens udlægning af Grundtvig-begreberne, der samtidig har karakter af spidsformulering eller samlende udsagn, finder man i hans tolkning af gudstjenesten som en form for kommunikation:

Kirken er forst og fremmest den kommunikation, der sker, når livsordene skaber livsudtrykkene, som ytrer sig i livstegnene, som umiskendeligt er tegn på, at her har vi at gøre med Jesu Kristi kirke, for hvem skulle vel ellers bryde ud i denne form for bekendelse, forkyndelse og lovsang? (107).

Med introduktion af livsudtryk og livstegn - begreber, som er blevet til under inspiration fra Grundtvigs Den Christelige Børnelaerdom ( $V U$ VI, 79 ff.) - var Hans Raun Iversen blandt de første - nok egentlig den første - der greb fat i erfaringsdimensionen i Grundtvigs teologi, dels på baggrund af Grundtvigs egen begrebsverden, dels gennem sin egen optagethed af socialisationsteori:

Samtidig gentager livstegnene, der er menneskers respons på det nye liv i kristen tro, håb og kærlighed, så at sige livsordene, som således gives videre til andre mennesker til liv og tro. Først og sidst er det dog Gud, Helligånden, Sønnen og Faderen, der handler i og med denne kirkens indre kommunikation. Grundlæggende tænker Grundtvig altid teologisk (...). Når mennesket er rustet til at indgå i denne kommunikation, skyldes det, at vi er skabt treenige i den treenige Guds billede: mennesker er udrustet med ånd, sjæl og krop, med hånd, mund og hjerte - og med kraft, sandhed og kærlighed (...). For Grundtvig flyder kirkens, frelsens og menneskelivets trefoldige struktur ud af Guds treenighed (107).

I de senere år har interessen for en erfaringsteologisk læsning af Grundtvigs forfatterskab været stigende. På visse punker ligner Hans Raun Iversens Grundtvig-tolkning her Svend Bjergs, når denne beskriver hverdagen som stedet, hvor man forstår og fortolker de grundlæggende livserfaringer, men Hans Raun Iversen betoner - i god overensstemmelse med Grundtvig - erfaringens kropslige side, hvor Svend Bjerg med udgangspunkt i narrativ teologi som fortolkende i forhold til fænomenologi arbejder temmelig anderledes. Hans Raun Iversen tager udgangspunkt i Grundtvigs forening af ord- og sanselighedsteologi, idet han med Grundtvig peger på tro håb og kærlighed som menneskelige såvel som kristelige fænomener:

Sammen med Paulus, Luther og Grundtvig vil jeg mene, at kristendommen som empirisk foenomen kan beskrives og forstås som et liv, der er præget af tro, håb og karlighed med Kristus-orientering. Kristendommen forstår jeg altså som liv - og i den forstand som noget empirisk, modsat noget blot principielt, teoretisk eller på anden måde for erfaringen utilgængeligt. Og saekulariseringen forstår jeg som følge 
heraf som udtryk for, at liv med Kristus-orienteret tro, håb og karlighed traenges tilbage (Raun Iversen 1982, 23-24).

I Hans Raun Iversens studietid var der i Århus en stærk skole, der læste Grundtvig med udgangspunkt i Løgstrup. Det førte til spændende vinkler på forfatterskabet, men også en fortolkning, hvor Grundtvigs menneskesyn næsten restløst gik op i Løgstrups begreb om det førkulturelle - og dette forhold forskød således vægten fra de områder, Grundtvig satte fokus på, historie og kultur, uden at man gjorde sig dette forhold klart. Grundtvig kan godt sige noget alment om gudbilledligheden, men hans sigte er det levede liv, den konkrete historie. Hans Raun Iversen er i højere grad på linje med Grundtvig, når han frem for det før-kulturelle arbejder med erfaringer og ændringer i social- og livshistorien - og dette gør det også muligt at holde blikket åbent for forholdet mellem skabelse og genløsning, idet Hans Raun Iversen således bevæger sig ud over Løgstrup-skolens forskydning af vekselvirkningsforholdet til første trosartikel og under inspiration fra Anna Marie Aagaard, som giver ham en frugtbar indfaldsvinkel til Grundtvigs åndsteologi, kan tale om Helligåndens virke i menneskets historisk bestemte liv. Man er her ved selve livsåren i Raun Iversens Grundtvig-tolkning, det der udgør kontinuiteten i hans arbejde fra hovedværket And og livsform fra 1987 og frem til den nyudgivne antologi. Selvom denne indeholder bidrag fra alle årene, fremstår den dog står som et særdeles nutidigt og aktuelt værk. Med baggrund i socialisationsteori kunne Raun Iversen dengang skrive om sammenhængen mellem ånd og livsform:

Det er ånden, der giver liv i livet. Med den står og falder det hele. $O g$ ånd er kraft, livskraft, der ytrer sig i samtale, forudsætter frihed og altid virker i, med og under en bestemt form, en livsform. Formerne kan dø, fordi der ikke længere er ånd i dem, men ånden kan kun leve i konkrete former - de være sig aldrig så midlertidige og skrøbelige (Raun Iversen 1987, 9).

Erfaringsteologiens kommunikative side er til stede også i den nye udgivelse, således når Raun Iversen bringer tolkningen af den alt for tit forsømte grundtvigske Helligåndsteologi videre og præcist skriver om Grundtvigs åndsbegreb:

Anden er ikke en kvalitet hos det enkelte menneske. Den er i bund og grund noget kollektivt, som tilhører fællesskabet mellem mennesker, Ånden er altid livet i livet, ikke noget, som vi kan kommunikere med, for den er selve kommunikationen mellem mennesker og mellem Gud og mennesker: ånden er midt $\mathrm{i}$, ja den er kraften i alt, hvad der sker med os, når vi virkelig lever, det vil sige åbner os, giver og modtager, lytter og taler til hinanden, lærer af historien og pejler fremtiden (85). 
Menneskeliv er altid samliv - og netop derfor er menighedslivet og den teologiske refleksion derover så afgørende for Hans Raun Iversen. Med sin fokusering herpå har han kunnet pege på vigtige træk $\mathrm{i}$ Grundtvigs forfatterskab, træk, der forekom indlysende, så snart de var draget frem, men indtil da knap måtte nævnes. Sider af Grundtvig og det grundtvigske, der var glemt - eller snarere undertrykt - er blevet bragt frem i lyset igen. Det mærkelige er jo, at den thaningske adskillelsestese ikke blot udhulede forståelsen af kristendommen - den udhulede også forståelsen af menneskelivet, selv om det næppe har været Thanings mening - han ønskede jo ikke at suspendere tanken om menneskelivet som forståelsesramme for kristendommen, men det var det, der skete. Når forholdet de to imellem kunne nedskrives til, at kristendommen satte menneskelivet fri, var det ikke mere nødvendigt at sige noget indholdsfyldt om menneskelivet. Selve modellen, adskillelsestesen, blev tolkningens indhold. Men netop vekselvirkningsmodellen gør det nødvendigt at bevæge sig ind i menneskelivet at tale om træk ved det, som kaster lys over kristendommen - og så bliver det også nødvendigt at tale om, hvad kristendommen er, hvad det er, der vekselvirker med menneskelivet.

Hovedværket i Hans Raun Iversens forfatterskab var og er bogen And og livsform. Der er ikke blot tale om en klar og tydelig identifikation af hovedlinjer i kirkesynet fra Grundtvig og frem til i dag, men også om fremdragelse af et yderst vigtigt, men overset forhold $\mathrm{i}$ forbindelse med mennesker og kristendom: forbindelsen mellem de daglige erfaringer i intimsfæren, "huslivet" og kristendommen, det forhold at der nødvendigvis må være sammenhæng mellem livsform på den ene side og forkyndelse og teologi på den anden side. Men And og livsform forudsætter og lever af de andre analyser, hvoraf nogle af de mest betydelige er samlet i den foreliggende bog. Det afgørende greb, der som praktisk teologi i københavnsk forstand både præges af systematisk-teologisk stringens og samtidig lader sig anvende i kirkehistorikerens arbejde med at systematisere kilderne, er bestemmelsen af Grundtvigs kristendomssyn som inkarnatorisk. Her samles indsigterne fra Theodor Jørgensens Grundtvig-tolkning og den århusianske Grundtvig-forskning i årene op imod Grundtvig-jubilæet i 1983 samtidig med, at foreningen af socialisationsteori og missionsteologi med et begreb, der ikke bruges: kontekstuel teologi - åbner for nye indsigter, inddrager menneskelivet og gør det muligt at tolke Grundtvig som erfaringsteolog i direkte tilknytning til det begreb om sansning og erfaring, der helt fra Danne-Virke-tiden i 1810'erne står i centrum i forfatterskabet. Med fokuseringen på erfaringsbegrebet har Hans Raun Iversen åbnet op for nye indsigter i Grundtvigs forfatterskab - indsigter, der ikke blot beriger Grundtvig-forskningen, men 
også uddyber vores forståelse af, hvad det vil sige at være menighed en indsigt, der er forholdsvis svagt fremstillet i den aktuelle bogs Grundtvig-afsnit, men står des stærkere i And og livsform. Selve det forhold at - med Hans Raun Iversens egne ord - "troen såvel efter sin menneskelige art som efter sin guddommelige bestemmelse for Grundtvig at se (...) på én gang [er] konkret og social, mærkbar og kollektivt orienteret" (57), medfører, at inspiration fra grundtvigsk teologi hos Raun Iversen er uløseligt forbundet med "fornemmelsen for, hvad begrebet om den levende menighed kan dække over i praksis" (62). Og netop fordi Hans Raun Iversen med baggrund i erfaringsbegrebet og bestemmelsen af Grundtvigs teologi som inkarnatorisk forstår betydningen af, at troen får skikkelse i verden, kan hans Grundtvig-tolkning også karakteriseres som en form for Helligåndsteologi, "kun Ånden gør Faderen og Sønnen levende for os" (81). "Det åndelige er det kommunikative menneskeliv, som inkluderer, men aldrig kan reduceres til det psykiske og kropslige" (91). Ånden virker livstegnene i menigheden, "nemlig den bekendelse, forkyndelse og lovsang, der svarer til troen, håbet og kcerligheden" (86). Hans Raun Iversen taler om, at Grundtvigs romantisk inspirerede åndsbegreb hele tiden afbalanceres "af hans næsten socialpsykologisk kvalificerede virkelighedssans" (87). Og netop fordi Ånden som Helligånd står centralt i Hans Raun Iversens Grundtvig-tolkning - samtidig med, at vekselvirkningen mellem kristeligt og menneskeligt betones - er det også muligt for ham at sige noget indholdsfyldt om Grundtvigs teologi i perspektiv af anden trosartikel, noget, som tit er meget vanskeligt for skabelsesteologisk orienterede grundtvigianere. Men medens det lykkes ham at fortolke erfarings-, ånds- og menighedsbegrebet i dets vekselvirkning mellem menneskeligt og kristeligt ind $i$ et nutidigt perspektiv, gøre det nærværende, har han - trods viljen til at forholde sig positivt til den - større vanskeligheder med den kirkelige anskuelse.

Denne kritik skal uddybes nedenfor, hvor der afsluttende fremsættes nogle kritiske indvendinger. Nogle af dem går på det rent fortolkningsmæssige, på Grundtvig-eksegesen så at sige, nogle af dem berører principielle spørgsmål og problemstillinger, der har direkte betydning for teologisk tænkning og menighedsliv i dag, nogle af dem angår Hans Raun Iversens metodiske tilgang til studiet af Grundtvig.

Grundtvig-eksegesen først. Hans Raun Iversen begyndte som Grundtvig-forsker i en tidsalder, hvor Grundtvig-kritik ikke var almindelig. Grundtvigs 200 års fødselsdag blev fejret i hele det danske samfund - uden at kritikken overskyggede festen. Hans Raun Iversen var imidlertid en undtagelse. I afhandlingen Grundtvig som inspiration til mission fra 1983 lægger Raun Iversen ikke skjul på, at Grundtvig 
graduerer folkeslagene efter deres udviklingstrin - at han i Mands Minde karakteriserer negrene som "raa og vilde Folk" (72), og han føjer kritisk til at "I dag ved vi, at alle er født principielt lige, uanset at vi af vores kulturer og personlige historie bliver formet forskelligt" (73). Ligheden er vor tids indsigt - men det forekommer mig, at Hans Raun Iversen - trods sin berettigede kritik af Grundtvigs graduering godt kunne have fundet udsagn, der kaster et anderledes lys over forfatterskabets billede af såkaldt primitive folk. I Danskeren drøfter Grundtvig således, hvad den europæiske kultur har bidraget med hos "Hottentotter, Irokeser og Eskimoer" - og han føjer til, at disse folkeslag endnu er i deres barndom - hvilket ikke nødvendigvis er en negativ karakteristik, selv om det for Grundtvig medfører, at disse folk ikke kan være førende i menneskehedens udvikling. Grundtvigs svar er interessant: netop dét kan vi ikke udtale os om - de eneste, der kan sige noget om, hvad den europæiske kultur har betydet for dem, er de primitive folkeslag selv. I Grundtvigs svar ligger der en radikal og spændende myndiggørelse af mennesker og folkeslag gemt - også sådanne, der befinder sig i deres barndom. $\mathrm{Nu}$ er det ikke at forlange, at Hans Raun Iversen skal rundt i alle krinkelkroge af forfatterskabet men måske kan man på dette sted udtale som et ønske, at der sættes en større undersøgelse af Grundtvigs folke- eller kulturpsykologi i gang antropologen Ole Højris og dr. phil. Ole Vind har næsten været ene om at beskæftige sig med det og har tegnet et meget negativt billede. Men man kunne måske nok forlange, at Hans Raun Iversen $\mathrm{i}$ den foreliggende bog havde bevæget sig ind i et emne, der er beslægtet hermed - folkelighedsbegrebet, som i de senere år har måttet stå for skud. Det grundtvigske folkelighedsbegreb kommer næsten til at stå som en given, ikke-kritiserbar forudsætning - kun nævner Hans Raun Iversen, at han i And og livsform "har beskæftiget sig indgående med Grundtvigs tidshistorisk bestemte begreb om det folkelige" (44) - men i dette værk nævnes det nærmest kun en passant, at Grundtvig "hører til blandt 1800-tallets romantiske nationalister i Europa" (Raun Iversen 1987, 70). Havde Hans Raun Iversen forholdt sig kritisk til den essentialisme, som præger sider af Grundtvigs folkelighedsbegreb, havde hans arbejde stået stærkere - også selv om han sideløbende hermed havde arbejdet med at læse folkelighed som en historisk givet kultur i forandring frem $i$ teksterne.

Noget lignende kan siges om Hans Raun Iversens arbejde med selve kernen i Grundtvigs kristendomsforståelse, den kirkelige anskuelse, som den her skal kaldes i tråd med Grundtvig selv, Grundtvigs teologi om mundsordene - dåbsordet, sakramenternes indstiftelsesord, fadervor og fredlysningen - som bærende i kristendommen. Hans Raun Iversen gennemfører en berettiget kritik af Grundtvigs lære om 
apostolicum som overgivet af Jesus til apostlene i "de 40 dage" mellem opstandelse og himmelfart, men når han selv skal argumentere for, at "trosbekendelsen - ligesom fadervor og indstiftelsesordene - meget vel kan "fastholdes som ord, der sagligt og elementært står i kontinuitet med Jesu egne ord og virke" (109-110), kunne det synes, som om det element af almen tilgængelighed, Grundtvig tillagde trosbekendelsen, træder tilbage for en formidlende og nødvendig teologisk argumentation - som Hans Raun Iversen så ikke gennemfører. Det synes, som om Hans Raun Iversen selv ikke er langt fra det element af konservativ teologi, han med rette finder i Grundtvigs forfatterskab men en gang imellem forekommer det læseren, at han er mere optaget af at arbejde med kristendommens vekselvirkning med den menneskelige livsverden end med det lige så grundlæggende teologiske arbejde med den overleverede kristendom, åbenbaringen og dens historiske formidling til os i dag.

Dette hænger igen sammen med mit sidste kritikpunkt. Hans Raun Iversen bevæger sig i sin Grundtvig-tolkning inden for de store, tværgående linjer. Han formår at trække de grundlæggende træk i forfatterskabet frem, og han kaster lys over dem gennem sine missionsteologiske og praktisk-teologiske modeller i forening med humanvidenskabelige indsigter - alt med såvel en teoretisk som erfaringsbaseret tilgang. En sådan form for Grundtvig-tolkning rummer en række faldgruber. Det bliver alt for let at læse nutidige synspunkter egne synspunkter - ind i forfatterskabet, så den egentlige dialog med dette udebliver og en sand horisontforskydning mangler. Hans Raun Iversen undviger den fare, fordi han så flittigt inddrager anden Grundtvig-forsknings specialstudier, fordi han er i stand til at medtænke kritik i sit tolkningsarbejde, og endelig fordi han formår det, meget få gør - at lade sine udefra kommende modeller og erfaringer kaste virkeligt nyt lys ind over forfatterskabet og derved fremdrage hidtil glemte eller oversete elementer heri. Og netop derfor har hans arbejde med Grundtvig kunnet give andre nye erkendelser, eksempelvis, som med bogen And og livsform kunnet give den nuværende grundtvigske bevægelse adgang til de erfaringer med menighedslivet, som den bærer med fra fortiden, fra perioden frem til tidehvervsgrundtvigianismens dominans - netop erfaringerne, der også for Hans Raun Iversen hører med i ethvert redeligt stykke teologisk arbejde.

Nærværende anmeldelse har overvejende holdt sig til bogens Grundtvig-afsnit. Men Grundtvig er også til stede i bogens øvrige arbejder - ligesom Hans Raun Iversens kritik af grundtvigianernes Grundtvig-tolkning, og her i særdeleshed deres tolkning af Grundtvigs kirkesyn. Hans Raun Iversen konstaterer, at grundtvigianerne i vor tid endnu engang har vendt 180 grader - fra det ordningskirkelige syn til 
en fornyet interesse for menigheden, i lighed med de øvrige gamle kirkelige retninger. Hvis man ikke som Hans Raun Iversen beklager, at Grundtvig, Luther og Kierkegaard er "kirkeordningsmæssige anarkister" (108), kunne det - i modstrid med Raun Iversens konstatering i disse år godt synes, som om ledende kirkepolitikere forveksler menighedsliv med struktur og dermed kapper forbindelsen til de erfaringer med menighedsliv, der eksempelvis er at finde $\mathrm{i}$ de grundtvigske valgmenigheder. Selv om valgmenighederne nok med Hans Raun Iversens ord har "tilpasset sig den almindelige folkekirkelighed" (127) igennem det 20. århundrede, gælder det kun folkekirken som ordning, som ramme - indadtil ved vi som regel godt, hvad et menighedsliv vil sige, også et menighedsliv, der, som Hans Raun Iversen selv har konstateret det i And og livsform, i sin tilknytning til livsformer og menneskelig kærlighed herigennem, i forlængelse af Grundtvig har fokuseret på venskabsbegrebet som afgørende.

Når der her afsluttende knyttes positivt til ved Raun Iversens arbejde, sker det helt bevidst: med nærværende bog i forening med And og livsform har han givet et yderst væsentligt bidrag til studiet af Grundtvigs inkarnationsteologi, Helligåndsteologi og menighedsteologi, et bidrag, der ikke blot fortjener læsere $\mathrm{i}$ forskernes cirkler, men også blandt præster og lægfolk i den menighed, han med sit praktisk-teologiske arbejde reflekterer over.

\section{Litteraturliste}

Iversen, Hans Raun (1982), Tro, håb og karlighed. Scekularisering og socialisation grundtvigsk forstået, Århus.

- (1987), And og livsform. Husliv, folkeliv og kirkeliv hos Grundtvig og sidenhen, Århus.

$V U$ VI: Bind 6 i Georg Christensen og Hal Koch (udg.) (1940-49), N. F. S. Grundtvigs Verker i Udvalg, bind 1-10, København. 